\title{
TRANSLATION ANALYSIS OF DIRECTIVE SPEECH ACTS IN THE OLD MAN AND THE SEA NOVEL AND ITS TRANSLATION INTO INDONESIAN
}

\author{
Sri Sugiharti \\ English Department, Teacher Training and Education Faculty, University of Riau Kepulauan, Batam, \\ Indonesia \\ Email: srisugihartiwismono@gmail.com
}

\begin{abstract}
Translating utterances is not similar to translating sentences. It requires special attention as there is an intended meaning or message transferred by a speaker to a hearer. Context of the situation overshadowing the utterance must be obeyed carefully. Thus the messages will be easily revealed. Speech act is a way that allows the messages of utterances to be seen. The focus of speech act is illucution since it shows the intention of utterances uttered. It is also much correlated with translation. In translating an utterance, it is not merely translated literally, but there is also an intention that should be translated. This paper is aimed to analyze directive speech act in The Old Man and The Sea and its translation into Indonesian. It tries to reveal the functions of directive speech acts, translation techniques used and the translation quality (readability, accuracy, and acceptability).
\end{abstract}

Keywords: translation analysis, directive speech acts, The Old Man and The Sea novel

\section{INTRODUCTION}

Translation is identical with communicating the message or idea. That is written in original text. When we talk about the form of a language, we are referring to the actual words, phrases, clauses, and sentences which are spoken and written. It consists of transferring the meaning of the Source Language (SL) to Target Language (TL). Thus, translation in other words is 'a bridge' to over come a person's in ability to obtain specific information due to language barriers. Along with the times, much information transmitted is expanded and developed like transmitting information of technology up to information of cultural exchange as like literary works translation.

Now days, many translated fictions are easily found in the bookstore. Translated from the novel The Old Man and The Sea, by Ernest Hemingway. 
Lelaki Tua dan Laut is one of the many translated literary works translated into Indonesian. This novel became very phenomenal and successful in the market since its selling rate in the first week of publication around 35.000 copies. This novel then to be very interesting because it contains wonderful inspiration of gaining happiness through radically life changes as the author did when she is 30 years old. The success of this novel can be a truthful evidence to be researched. Analyzing utterances produced by some characters inside the novel could be an interesting choice.

Translating utterances requires special attention as there is a message or intention meaning transferred by a speaker or a writer to a hearer or reader. There are some things should be obeyed such as context of the situation over shadowing the utterance, speakers and listeners' social level, and the content of the utterance. However, some miss understanding may occur between speakers or hearers. Consequently, the message will not be easily well transmitted as the way it is. Some ways to avoid this kind of miss understanding is by learning about speech acts could not get their messages across due to a different cultural background of divergences it.

Fawcett (1997) proposes the relationship between illocutionary speech act and translation, "However it is translated, illocutionary force of the sentence would not change." In translating a speech, a good result of translation should be equal in term of type and function. In other words, speech translation is not merely translated literally, but there is also an intention that should be translated. A translator must concern this. For example, if the illocution of SL directive, in TL should be directive too.

This study is focused on the speech act translation as Fawcett (1997) states that speech actor speech act is a part of Pragmatics that much correlated with translation. Directive speech acts are selected due to the plot conformity of the novel. In The Old Man and The Sea there are a lot of wonderful inspirations and powerful motivations as the author got during her own experiences that can make there adders especially women learn to be stronger and independent. So, there will be many directive speech act found there. 
Hence, this research conducted to reveal the functions of directive speech acts and its translation into Indonesian.

\section{THEORITICAL REVIEW}

\section{Speech Act Theory}

Speech act theory (SAT) is one of the core issue of modern pragmatics, as stated particularly by Austin (1962) and then expanded by Searle (1969). It is one of pragmatics' basic ingredients arranging by words and corresponding to sentences and some ways to avoid kinds of misunderstanding in communication (Schiffrin, 2001: 49). The speech act of any language provide its speakers with culture-specific categories of verbal interaction. Speech acts can shed a great deal of light on broader cultural themes, but equally the significance of any particular speech act category can only be fully understood in broader cultural context (Abdullah, 2012). Further, cultures may differ in the rules when certain speech acts can be appropriately performed. (Benthalia and Davis, 1989: 102 in Abdullah 2012).

In showing their feeling, people should express it by uttering words and also perform actions via those utterances. By producing utterances, a speaker transmits a message to a hearer. Actions that are performed through utterances are generally called speech act. Austin divided speech acts into three elements: locution (saying something with a certain meaning in traditional sense), illocution (the performance of an act in saying something/ the speaker's intent/ the true of speech act), perlocution (an effect on the feelings, thoughts or actions of either the speaker or the listener).

According to Searle, one can perform only five basic of actions in speaking, by means of the following types of utterances: representative (committing the speaker to the truth of the expressed proposition), directives (making the hearer to do something), commissive (the speaker commits himself to a certain course of a action to be taken in the future), expressive (expressing the speaker's feelings, and declaratives (bringing out a change in the external situation of the world through utterances. 


\section{The Concept of Directive Speech Act}

When the speaker asks the hearer to do something, it means that the speaker performs a speech act. He/She certainly wants his/ her action to be understood and the the hearer will do what the speaker wants. According to Searle (1969) in Martinez (2005: 169), language is a part of a theory of actions, and speech act are those verbal acts, or more precisely illocutionary act, such as directive, commisive, assertive, etc.

Directive speech acts often happens around us. They are essential actions in social interactions, as also in movies and novels. When a speaker ask the hearer to do something, it means that the speaker perform a speech act called directive. Yule (1996: 54) states that in using a directive, a speaker attempts to make the world fit the words via the hearer.

Bach and Harnish's (1979) in Martinez (2005: 169) definition of directives also implies that the speaker's attitude and intention when performing an utterance must be taken as a reason for the hearer's action. Trosbog (1995: 20) in Martinez (2005: 169) points out, "only in the case of directives is the hearer's subsequent act (getting things done) part of the speaker's intention". Therefore, dealing with directive speech act, both the interlocutor's presence and their response to speaker's intentions are fully required, since the action will only be fulfilled after the hearer's acceptance of the speaker's intentions.

Focusing specifically on the different speech act included within the group of directives, Schmit and Richards (1980) claim that it contains speech acts such as request, commands, suggesting, advicing, and forbiding, challenging, begging, instructing, warning, etc. The main goal of which is to get the hearer to do something, although the force of the attempt can differ from speech act to another.

\section{Techniques of Translation}

Analyzing translation techniques allow us to study the way translation works. Molina and Albir, 2002: 499 suggest that procedures refer to the final 
result of translation that should be called techniques rather than procedures. They proposed fifteen techniques used in written translation:

Analyzing translation techniques allow us to study the way translation works. Molina and Albir, 2002: 499 suggest that procedures refer to the final result of translation that should be called techniques rather than procedures. They proposed fifteen techniques used in written translation:

\section{Adaptation}

Replacing a ST cultural element with one from the target culture, e.g., to change hide and seek in English into petak umpet in Indonesian.

\section{Borrowing}

Borrowing is the taking of words directly from one language into another without translation, e.g., bulldozer

\section{Calque}

A literal translation of a foreign word or phrase; it can be lexical or structural, e.g., English translation 'bamboo windmills' into 'baling-baling bambu' in Indonesian.

\section{Literal translation}

Word for word translation, e.g., "I need you "become" Aku membutuhkanmu." in Indonesian.

\section{Transposition}

A shift of word class (changing the word for the phrase instead of keeping the word and writing), e.g., 'pebble stones' is translated into Indonesia 'kerikil'.

\section{Modulation}

To change the point of view, focus or cognitive category in relation to the ST; it can be lexical or structural, e.g., "Nobody doesn't like it" into "Semua orang menyukainya”.

\section{Generalization}


Using a more general term, e.g., 'penthouse', 'mansion' into 'tempat tinggal'.

\section{Reduction}

To suppress a ST information item in the TL, e.g., 'SBY the president of republic of Indonesia' into 'SBY'.

\section{Particularization}

To use a more precise or concrete term, e.g., 'air transportation' into 'pesawat'

\subsection{Short Synopsis of The Old Man and The Sea}

"The Old Man and The Sea" talked about Santiago, the old fisherman which full of experience. But in a time, he passed eighty four days without cough nothing. In the society then he called as "salao" it was the worst form of unlucky.

Because of the called, Manolin, a small boy who often help him, was forbidden by his parents not to help Santiago and help others fisherman which was more success and more cough the fish. How sorrow he was if a fisherman called unable more to catch fish.

At the eighty fifth day, Santiago went to sail alone to Gulf Stream which laid in Atlantic ocean. Gulf Stream itself famous as a heavy current. At noon, the feed of the fish ate by huge Marlin fish. He couldn't able to hold back the fishing line, even he withdrawn back by the fish.

It was happening in few days. Although he got pain, feeling hungry and tired, he kept last. He felt very happy in his successful got a big Marlin fish. He imagined that how expensive it was if it sold in the market.

\section{METHODOLOGY}

This study is designed as a descriptive qualitative research because the data collected are in the form of words rather than numbers. This research is aimed at understanding the phenomena such as behaviours and actions holistically and descriptively in words in a specific context by using natural method or certain theories (Moleong, 2006; p. 6). This study is categorized into product-oriented translation research focusing on the product of 
translation. The study was conducted by reviewing the directive illocutionary speech acts in the novel The Old Man and The Sea translation into Indonesian, uncovering translation techniques used and how the quality of its translation. The data were examined are directive illocutionary speech act presented in the novel The Old Man and The Sea from 108 chapters taken randomly. Thus there are 20 data selected to be analyzed.

\section{FINDINGS}

\section{Findings of Directive Illocutionary Functions}

From 20 data, there are four illocution's functions found, namely commanding, advising, forbiding, and suggesting with the following composition, 10 data (50\%) of commanding functions, 4 data (20\%) of advising functions, forbidding has 3 data (15\%), and 3 data (15\%) of suggesting. Here are the descriptions of each directive illocutionary functions along with examples in the findings of this study:

\section{a. Commanding}

Commanding means giving order or asking the other persons to do something. Here's the example of commanding function found (data 3/ ch 9): ST: "Go a head. Answer the ring!"

TT: "Angkatlah. Jawablah telepon itu!"

\section{b. Advising}

Advising is giving an opinion and precept to someone. Advising function of directive speech offers someone what should do or how to act in a particular situation. An advice tends to be positive. Here's an example of advising (data5/ch20):

ST: "Liz, you must be very polite with yourself when you are learning something new."

TT: "Liz, kaтu harus lebih sabar jika kamu belajar sesuatu yang baru."

\section{c. Forbidding}

Forbidding is defined as someone was allowed to do something or not do something. In terms ofthe function of speech, forbidding means asking 
hearer not to do something. Here's an example of forbidding function findings (data6/ch26):

ST: "Don't ask these questions!"

TT: "Jangan ajukan pertanyaan- pertanyaan itu lagi."

\section{d. Suggesting}

Suggesting means communicating an idea or feeling to consider or recommending something. The function of suggesting directive speech act is intended to make the hearer consider matters presented by speakers. Furthermore, hearer is willing to follow the suggestions given. The examples of suggesting illocution as follows (data12/ch48):

ST: "Give it another six months, you'll feel better. Give it another six months, you'll feel better."

TT: "Sebaiknya beri tambahan waktu enam bulan lagi dan kamu akan merasa lebih baik.

Pragmatic shift between SL and TL is also occurs in this study. It can be the shift of thet ypes of SL's illocutionary force is different from TL's. For example, SL's illocution type is assertives but translated into an interrogative directive in TL, as shown in the following example found in the analysis (data18/ch51):

ST: "Then perhaps madam would like to hang a rug on her wall."

TT: "Mungkin nyonya mau menggantung karpet ini di dinding?"

In addition, the shift of illocutionary functions may happens; such as a directive speech act with commanding function which is translated into a directive speech act with begging function. Here is example of a case found (data12/ch48):

ST: "Give it another six months, you'll feel better."

TT: "Sebaiknya beri tambahan waktu enam bulan lagu, kamu akan merasa lebih baik." 


\section{Finding of Translation Techniques.}

After analyzing 20 data, it is found six techniques of translation in a single variant, and couplet translation with the frequency of use 21 times. The techniques applied include literal translation 8 times (38, 09\%), borrowing techniques twice (9.52\%), 4 times of reduction techniques (19.04\%), adaptation 4 times(19.04\%), 3 times of addition (14.28\%), and linguistic amplification once (4.76\%). Here are the detail explanations of each variant:

\section{a. Single Variant}

Single translation technique refers to the application of one technique in a speech act (utterance). Some techniques used in this variant are literal translation, reduction, adaptation, addition and linguistics amplification.

\section{1) Literal translation}

A word-for-word translation can be used in some languages and not others dependent on the sentence structure. This techniqueis applied to translate literally. Adjustment of TL's structure is an important partin appliying this technique. In this study, literal technique is applied to eight data. The example ofthe literal technique used single variant is below (data14/ch48):

ST: "Stop using David to block that door!"

TT: "Berhenti menggunakan David untuk menghalangi pintu itu."

2) Reduction

This technique is applied to partial removal. Some elements of the TL is eliminated. The information is implied, so it does not appear explicitly in TL. The use of reduction techniques in the study contain four speech acts, for example (data20/ch105):

ST: "Then you must spoil him!”

TT: "Kamu harus memanjakan dia!"

3) Adaptation

Adaptation means are placement at SL's cultural elements with cultural elements that existon TL. In this study, there are four data was identified 
using adaptation techniques. Here's an example ofthese findings (data11/ch29):

ST: "Look at little Mary sunshine now!"

TT: "Lihatlah sekarang pada anak yang selalu beruntung ini!"

4) Addition

Addition techniques performed by adding the implicit information in TL. There are three speech acts of data in this study using additional techniques, such as the following (data $1 / \operatorname{ch} 9)$ :

ST: "Take a nap!"

TT: "Tidurlah sebentar!”

5) Linguistic Amplification

The application of this techniqueis done by adding the inherent linguistic elments implicitly on TL This technique is applied to the following data (data 4/ch16):

ST : 'I'd really rather than you didn't/

TT: "Saya lebih senang kamu tidak melakukan itu

\section{b. Couplet Variant}

Couplet variant means the combination of two translation techniques in a sentence. In this analysis, it is also found the combination of two techniques used in a speech (an utterance. They are data 8 and 9. Here's an example of couplet variant findings, the literal technique and pure borrowing (data9/ch27):

ST: "Order the margherita pizza with double mozarella."

TT: "Pesanlah margherita pizza dengan double mozarella."

\section{Translation Quality of Directive Speech Acts}

The quality of translation consists of three aspects, i.e the accuracy, acceptance, and readability. In terms of accuracy, 17 data (85\%) is considered as accurate translations, 2 data (10\%) are less accurate, and 1 data (5\%) are not accurate. Based on the level of acceptance, 18 of data (90\%) identified is acceptable and 2 data (10\%) are less acceptable. In terms of readability, there are 18 data $(90 \%)$ classified into high readability (easy to understand) and 2 data 
(10\%) with a low readability. Here's an example of data which is accurate, acceptable, and easy to understand:

ST: "Go away!"

TT: "Pergilah!"

\section{DISCUSSION}

\section{Implementation of Directive Illocutionary Functions}

This study examines the directive speech acts found in the novel The Old Man and The Sea works Ernest Hemingway. Searle (1979: 1-30) divided into five types of utterances include assertive, directive, commissive, expressive, and declarations. George Yule (1996: 53-54) divides speech acts into five general types of functions, namely the declaration, representative, expressive, directive, and commissive. These two opinions have different distribution of speech types, but not on the directive. Directive speech indicates asking the hearer to do something. Each type of directive speech acts premises is the object of study is examined. There are four functions of directive speech act found in this study such as, commanding, advising, forbidding, and suggesting.

Directive illocutionary function is dominated by commanding that was found in 10 data (50\%). This dominance findings are equal to the content of the novel, which is about a woman's attempt to find true happiness by traveling to three different countries. On her way, she's getting a lot of advices from a friend. Commanding directive illocutionary functions identified by speakers who have a more superior position to the hearer. Superiority may be due to the more expert speakers with a lot of experiences about love, as the following example:

ST: “Then you must spoil him!”

TT: “Kamu harus memanjakan dia!

The next directive illocutionary function found is advising. This function is applied to 4 data (20\%). The application of this function is based on the contents of the speech topic. Speakers' utterances have positive values to the good of hearer. The hearer is expected to follow the advice. The application of 
this function is shown by Giovanni, a new friend Liz when in Italy. He is trying to recover Liz's feelings after getting divorce by learning new things in Italy:

ST: "Liz, you must be very polite with yourself when you are learning something new."

TT: "Liz, kaтu harus lebih sabar jika kamu belajar sesuatu yang baru."

Subsequently, there are 3 data (15\%) found with the forbidding function of directive speech act. Forbidding functions means telling the hearer not to do something. Determination of forbidding function is similar to use of commanding function. The speaker's tendency is higher than hearers. This forbidding function is commonly marked by negative form as not, do not, never and at TL is marked by no, not. Here's an example of forbidding function found:

ST: "Don't ask these questions!"

TT: "Jangan ajukan pertanyaan- pertanyaan itu lagi."

The last, the directive illocutionary function found is suggesting. In this study, there are 3 data (15\%) with this function. Application of the suggesting function is supported by the context of the situation and the logical relationships of the speech. Suggesting function is characterized by utterances containing the advice of a certain event. Social position of this function is not always same as commanding functions. The finding of suggesting functions is made by Susanto Liz. Susan is Liz's friend:

Directive speeches in this study are identified in three different in construction: imperative, declarative and interrogative. Imperative is characterized by the use of verbs in early speech that directly contains errands. A declarative is constructed in a complete orders (subject, predicate and object) and contains a statement or declaration. Interrogative is in the form of interrogative sentence. The different construction affects the value of a sense a directive. Interrogative forms are more polite rather than the imperative form. Hence, the 
application of the directive illocutionary function is based on these two following important points:

1. The context of the situation that houses and logical relationships that are created in the speech

2. Social standing speakers and hearer, including distance relationship between the two.

\section{Dominance of Literal Translation Use}

There are 20 data (directive speech act) to be analyzed in this study taken from The Old Man and The Sea novel. After analysis, six translation techniques are identified used in the translation of the directive speech of the SL to TL. Based on the frequency of use of translation techniques, there are two variants of translation in implementing the techniques of translation; they are single variant and couplet variant. Single variant uses one techniques of data assessment while couplet uses two techniques at once. The variations of translation techniques frequency identified due to the characteristics of translation technique it self.

Utterances tend to have short simple sentence construction, especially in the novel. The complex sentences consisting of several clauses are rare. A simple form of an utterance is clearly to be seen from distribution of variants translation techniques. From 20 data, the sing levariant dominates much as 90\% and only 10\% variance couplet. From 6 translation techniques used, literal translation occurs 8 times $(38,09 \%)$, borrowing techniques twice (9.52\%), 4 times of reduction techniques (19.04\%), adaptation 4 times (19 ,04\%), and addition 3 times (14.28\%), and one data using amplification of linguistics (4.76\%).

The use a literal translation is the dominant findings of the other techniques. This technique is done by translating word for word from SL to TL. Object of this research study is directive speech act ting is Eat Pray Love. Characteristics of the data findings in this study is simply constructed and in the form of simple and short sentences. For example, the findings of the data "Go 
away!", "Take a nap!", And "Come!", Etc. These short constructions tend to use literal techniques.

Reduction techniques applied occur 4 times (19.04\%). In this study, the application of this technique is not considered as a problems in the object of the study is a literary work (novel), among the data are related to each other to uncover intended information. In addition, the delivery of meaning is supported by the author's narration, then the reader can still understand the story.

The application of additional techniques is found 3 times (14.28\%), and one data using linguistic amplification (4.76\%). It is done by making the meaning explicit in TL. Linguistic amplification techniques are applied by adding linguistic elements of SL in TL. Utterances like "I'd really rather than you didn't." which is translated into "Saya lebih senang kamu tidak melakukan itu. "The word "itu" is a linguistic element attached to the speech you did not. While the addition is proposed as more free addition techniques, for example, "Take a nap!" is translated into "Tidurlah sebentar!" This translation is used to make readers to understand the content of the speech easily.

Adaptation techniques performed 4 times (19.04\%). This technique is appllied the data containing elements of the culture that exists only in SL or exist only in SL. The application of this technique is commonly used in the idiomatic phrase which can not be translated literally.

ST : "Look at little Mary sun shine now!”

\section{SS : "Lihatlah sekarang pada anak yang selalu beruntung ini!"}

The last technique is the application ofa borrowing. This technique found in couplets variant twice $(9.52 \%)$. Pure borrowing in this study applied to the translation of the characters names, place names, and foreign terms. Foreign terms in this study based on the back ground of the story in this novel refers ring totypical food in Italia, like Pizzeria, margherita pizza and double mozzarella.

Application of pure borrowing techniques in this study is very appropriate. By pure borrowing, the nuance going to build in this novel that is introducing a 
typical Italian food can be delivered to the target readers. The target readers are adults, so it does not really matter in pronouncing or remembering names in foreign language.

\section{The Impact of Techniques to the Quality of the Translation}

From 20 data analyzed, the translation quality of directive speech acts in Eat Pray Love tend to have a good quality. Accurate translation dominates this research, so do the acceptability and readability. The data examined have a high level of acceptability and readability. In other words, the application 4 translation techniques tend to be good at translation quality of directive speech acts.

An accurate translation is influenced by the equivalence between SL and TL. The occuracy is influenced by the presence of some messages are not delivered while in accuracy is affected by the Accept a be translation adjustments are identified with the culture adjustments in Indonesian. Data that is less acceptable due to the violation of the norms of modesty in SL's culture. Finally, in acceptability is influenced the grammatical errors in SL, as in speech "Say as the strong and powerful man". Read ability level can be identified based on the easiness level of the data to be understood. Medium and low readability is affected by the use of foreign terms.

\section{CONCLUSION}

Translating utterances/ speech acts are regarded as a translation with high level of sensitivity. It needs particular attention from a translator since there is illocutionary force or intended message implied in a speech should be able to be revealed to the target language (TL). To do this, a translator needs to consider the context of the situation that over shadows a speech, speech topic content, social level of speakers and hearer. By having learned speech act we will be able to implement them in the social interaction in our daily life.

Dominant translation techniques used in this study is the literal translation techniques. This dominance is influenced by the data itself (the data in the form 
of speech). An utterance tend to be short and simply constructed. Furthermore, the similar constructions between SL and TL also play role in the dominance of this technique applied. The translation quality of directive speech acts in The Old Man and The Sea tend to have a good quality. Accurate translation dominates this research, so do the acceptability and readability. The data examined have a high level of acceptability and readability. Hence, the application for translation techniques end to be good translation quality of directive speech acts.

\section{REFERENCES}

Abdullah, Esbah Shaker \& Thomas Voon Foo. 2012. Offering as a Commissive and Directive Speech Act: Consequence for Cross-Cultural Communication. International Journal of Sciebtic and Research Publications, Volume 2, Issue 2, March 2012.

Austin, J.L. 1962. How to Do things with Words. Oxford: Clarendon Press.

Fawcet, Peter D. 1997. Translation and Language: Linguistic Theories Explained. St. Jerome Publishing,

Levinson, Stephen.1997.C. Pragmatics. Australia. Cambridge University Press. Martinez, Alicia. 2005. A Theoritical of the Speech Act of Suggesting: Towards a Taxonomy for its Use in FLT. Jaume I University. Revista Alicantina de Estudios Ingleses 18 (2005): 167- 187.

Moleong, Lexy.Metodologi Penelitian Kualitatif . Bandung. Remaja Rosda Karya. 2006.

Molina, Lucia and Albir, Amparo Hurtado. 2002. Translation Techniques Revisited: A Dynamic and Functionalist Approach. Meta: Journal des Tranducteurs/ Meta: Translators' Journal, vol 47, no 4. Page 498- 512.

Searle, John R. An Essay in the Philosophy of Language. New York. Cambridge University Press. 1974. 